\title{
Introduction: Kierkegaard and German Thought
}

Michael Stern

University of Oregon

\section{Moods, Voicing, and Anticipation}

Et Forord er Stemningen. At skrive et Forord er ligesom at hvæsse Leen, ligesom at stemme Guitaren, ligesom at snake med et Barn, ligesom at spytte af Vinduet. (Kierkegaard, SKS 4, 469)

A preface is a mood. Writing a preface is like sharpening a scythe, like tuning a guitar, like talking with a child, like spitting out of the window. ${ }^{1}$ (Kierkegaard, Prefaces 5)

If it would please you, dear reader, recall the vocabulary of the Kierkegaardian preface. Remember its lexicon, its love of secrets and self-effacements. Give heed to its masks, its pseudonymous authors who write pamphlets at their leisure, its editors who find manuscripts in secret compartments, its thieves in the night who copy diaries in anxious haste. Conjure up its sly seductions, its misdirections, its Chinese boxes, and its celebration of the chance occurrence. Bring to mind the aesthetics of a beginning that is never an origination for it is not possible for a thinker such as Kierkegaard to forward first principles or doctrines.

Kierkegaard seemed to relish the activity of composing introductions so much that he once wrote a book consisting of nothing but prefaces, introductions introducing nothing at all. He published Forord (Prefaces) in 1844, on the same day as Begrebet Angest (The Concept of Anxiety) - the first book conveying empty promises and the second possibilities without discernable objects. In the very first of Forord's (Prefaces) series of prefatory pieces, Kierkegaard's pseudonym, Nicolaus Notabene explains that his young wife's jealousy inspired the structure of the text. She had objected to him writing a full-fledged book because being "an author when one is a married man [...] is downright unfaithfulness [.]" (Kierkegaard, Prefaces 10). After much fruitless back and forth about the issue, Notabene's wife revealed that her previous objection was but a screen; the real reason for her opposition was married to her assessment of his literary potential; she said bluntly: "I do not think you are cut out to be an author 
[.]" (11). The argument continued affectionately and although he failed to see the logic of his wife's protestations, Nicolaus genially proposed that writing a book of just prefaces could serve as a compromise: "In this connection I appealed to analogies, that husbands, who had promised their wives never to use snuff anymore had as recompense obtained permission to have as many snuffboxes as they wished" (12).

If one cannot exercise the vice, one can collect the containers; if one cannot use the contents, one has a right to amass the forms. According to this line of reasoning, there is a form to faithfulness, but the content cannot be determined in advance. Notabene claims that there is a certain fidelity to positing without further articulation; Forord conveys the flirtation of language, an invitation without an event, a beginning without conclusion, a pregnant pause without issue. Perhaps if one considers the aesthetics of Kierkegaard's indirect communication, Forord represents a mís en abyme for his pseudonymous authorship, writing as a faithful anticipation of a reader to come, someone who will then superimpose her own text as an act of interpretation.

Putting the issue of form aside, let us return to the passage that crowns this, my own preface, as an epigraph. The word that Todd Nichol translates as mood, the Danish stemning, is also the word translated in its verbal form (stemme) as tuning, in this case bringing a guitar into proper pitch. This repetition in the passage is lost in the English, but is important to note. For a stemning can be a mood, an agreement, or a sense of accord. One resides within a mood though I would argue that one never inhabits a mood alone, and one tunes a guitar to realize its potential as an instrument, to enable it to conform to a musical composition, and out of consideration for the ears of the audience; so one tunes an instrument for oneself but also for others. ${ }^{2}$ Interestingly enough, stemme also means voice and if one is familiar with the Germanic languages, this word for sounding one's particularity also has a political meaning, a social implication; at stemme (at times rendered as afstemme) also means to vote. ${ }^{3}$ En Stemning, a mood, an attunement, a tuning, a voting and a voicing are all particular experiences that connect discrete moments and individuals to a temporal 
fullness, to that which precedes the moment, to others present and those yet to come. Kierkegaard's irony in Forord (Prefaces) resides in denying the reader that which follows, and in that manner, his irony serves as an invitation, a preface in advance of a meaning deferred. That said, I would also like to note that Stemning is the word used to crown a section of Frygt og Bæven (Fear and Trembling), which is translated as attunement by Alastair Hannay. ${ }^{4}$ In addition and as is commonly known, Martin Heidegger uses the German cognate Stimmung in Being and Time to indicate the mood, intrinsic to an existential ontology. The connotations are the same in German as in Danish.

However there is more to our epigraph. If Nicolaus Notabene is a protophenomenologist, one who understands that a mood, en stemming, eine stimmung articulates the preconditions, the preface to human comportment, perhaps his thoughts about prefaces also anticipate aspects of both deconstructive and Lacanian thought. For after he declares that a preface is a mood, likens it to tuning a guitar and sharpening a scythe, he compares it to talking to a child, and to spitting out the window. We have already touched upon how one cannot truly reap a semantic crop without a sharpened scythe, and an out of tune guitar plays a sour song; it follows that the preface, the stemning is intrinsic to what follows. The second part of the epigraph makes this even more interesting, for if one speaks to a child one never knows how it will be received (in both a negative or a positive sense-it is communication to a person as well as her potential), and spitting out of a window negates any aim or intention, for one certainly cannot foresee if one will hit the target. Thus it follows that if a preface is an attunement, a situation that precedes the possibility of voicing, no one ever knows on whose ears one's voice will eventually fall. ${ }^{5} \mathrm{~A}$ preface is a mood, an attunement, anticipating a body that will arrive and inhabit its space.

So what is the purpose of this ambling preamble, my own sense of an introduction? Friedrich Nietzsche will help me answer the question. In his own belated 1886 preface to Die fröhliches Wissenschaft (The Gay Science), he writes: " $\{\ldots\}$ I have asked myself often enough whether, on a grand scale, philosophy has been no more than an interpretation of the body and a 
misunderstanding of the body." (Nietzsche GS 5) ${ }^{6}$ I believe that what Nietzsche is trying to tell us here is that textualized philosophy is an unconscious memoir, but not of the bourgeois variety where the individual is reconstructed through a writing process regulated by intention, identification and excavation. Rather, philosophy for Nietzsche, and I believe for Kierkegaard as well, is a memoir of a stemning, eine Stimmung, in the sense that it is an articulation of a space-the segmentation, elaboration, and extension of a location that includes the body, and its situatedness as it radiates towards the future and towards future readers, bringing forward a history of the attunement that made the writing possible. If one continues to extend this interpretation, conveying the metaphor of philosophy as memoir further, relating it to Kierkegaard - it can be claimed that his texts are a location where there seems to be nothing personal but where everything that is personal is at stake. This seeming contradiction is the meaning of this preface to the volume, Kierkegaard and German Thought; the principle behind the essays does not reside within a notion of influence or influencing, but in the interaction of multiple discourses within a stemning, that which is the condition of possibility for an individual voice as it speaks with others, to others, and to texts carrying the words of others in citation.

That stated, if my discussion of Kierkegaard's Forord suggests that he becomes important for Heidegger, deconstruction and Lacanian inflected poststructural rhetorical analysis, how does Kierkegaard connect to the larger pantheon of German thinkers? What is the stemning that this volume will extend? What is the attunement from which Kierkegaard's work emerged, and how have his writings contributed to other philosophical environments?

\section{The Volume: Kierkegaard and German Thought}

One does not have to mine assiduously or dig deeply to encounter the rich vein of raw material that connects Kierkegaard to German thought. Some of the most glistening ore lies close to the surface. For a long time mainstream scholarship considered the mother lode to be Kierkegaard's textual encounters with the philosophy of G.W.F. Hegel and his attendance at the aging F.W.J. Schelling's 
lectures on the Philosophy of Revelation in Berlin held from the fall of 1841 through the winter of 1842. These moments are often considered to represent the onset of a wider split in the history of European philosophy, giving rise to what we now call existentialist philosophy or if you prefer, a movement of thought concerned with lived experience.

The early and persistent popularity of this position on Kierkegaard's encounter with German thought often hinges upon a contextual analysis, a description of a stemning. This intellectual environment was often described by emphasizing that the dominant philosophical discourse in Denmark during Kierkegaard's time was a type of Hegelianism refracted through thinkers like J.L. Heiberg and H.L. Martensen, and consequently most intellectual historians understand that Schelling's lectures offered an alternative perspective to Hegel. As a result, plenty of ink has been spilled describing and defining these encounters.

More than a few gallons have been used analyzing Kierkegaard's relationship to Hegelian thought and through the years two distinct positions have emerged; the pioneering work of Niels Thulstrup and a rejoinder to his thesis published by Jon Stewart. Thulstrup famously develops a rejectionist position where Kierkegaard only plays ironically at being a Hegelian while decisively rejecting his thought, and he claims that the two philosophers represent two radically different, almost antipodal strains of modern European philosophy. Stewart criticizes Thulstrup for not knowing Hegel well enough to understand the relationship between the two thinkers. He claims that the relationship is much more nuanced and does not hinge on Kierkegaard simply accepting or rejecting Hegel's work in its entirety; rather Stewart argues for a reading that considers a more complicated understanding of the relationship between the two thinkers. He argues for what he calls a "plurality" of relations. ${ }^{7}$

As mentioned, it is also common knowledge that young Søren was drawn to the work of Hegel's great rival, F.W.J. Schelling, whose Berlin lectures he attended in the fall of 1841. Schelling occupied Hegel's chair in Berlin after the latter's death and offered a different form of idealism for the young Dane to 
consider. These lectures are remembered (for better or worse) more for a rather famous trio in the audience than their content; Kierkegaard, Friedrich Engels and Mikhail Bakunin were all in attendance. In any case, it has been argued that Schelling's lectures marked a turning point in $19^{\text {th }}$ century philosophy, not because the audience bought his argument, but rather that two strains of thought both concerned with "existence" as opposed to idealism emerged. Some historians of philosophy trace the origins of existential thought through Kierkegaard's response to his disappointment with Schelling, ${ }^{8}$ and they also understand these lectures to be a seminal moment in the emergence of Hegelian Marxist discourse, as Engels felt compelled to defend Hegel against Schelling's critique. Consequently, until fairly recently Kierkegaard's relationship to modern German thought has often moved along the two trajectories tied to a classification of Hegel and Schelling's philosophical heirs; namely Western Marxism and existentialism. This has resulted in scholarship that addressed traditional modalities of influence; commentators trace the German existential tradition through Kierkegaard, Jaspers, and Heidegger, with Nietzsche occasionally thrown in for good measure. The ties that bind Kierkegaard to the Western Marxist tradition has solid grounds also as it was well known that Theodor Adorno, Walter Benjamin, and Georg Lukaçs all were engaged with Kierkegaard as young men, and that Adorno famously wrote his dissertation on the Danish thinker. ${ }^{9}$ In other words, until the late 1980s Kierkegaard's relationship to German thought ran along these familiar rails.

The rise of deconstruction, post-structuralism, and post-Marxist thought shed new light on Kierkegaard's importance for twentieth-century thinking. These movements have inflected the contributors to this volume of Konturen, Kierkegaard and German Thought on both the level of subject matter and methodology. For while there was a talk on Kierkegaard and Hegel at the conference where this volume was conceived, and there are scattered references to Schelling in the essays that follow this introduction; the essays in this collection represent the variety of discourses coursing through the intellectual veins and arteries of Golden Age Denmark while mirroring the multiplicity of 
concerns we share with that moment. In other words, rather than a reliance on singular models of influence and comparison, the editorial principle at work here favors a model designed to show the multiplicity of engagements in seemly singular discursive environments. This is especially important with regards to the textually enthusiast $19^{\text {th }}$ and $20^{\text {th }}$ centuries, and particularly important when assessing the polymathic and multi-vocal authorship of Søren Kierkegaard.

\section{Our Contributors: Reading Kierkegaard, Re-Reading Modernity}

In many ways, Kierkegaard's work speaks to complex collisions within European modernity. His engagement with the Greeks, the church fathers, medieval mystics, German romanticism, English poets, idealism, and his contemporary culture illustrate how modern discourse's historical consciousness brings contradictions into collision. His reception among thinkers seemingly antithetical to his sensibilities indicate that European modernity was never completely secular, and its conceptions of the ancient, the primitive, and its anticipatory temporal structures eventually give birth to many of our contemporary critical concerns. The contributors to Kierkegaard and German Thought shed light on several of these issues.

Gantt Gurley's “The Concept of Byrony” opens our volume. Gurley introduces and clarifies the complexity of the Danish Golden Age by challenging the idea that Kierkegaard's main authorial impulses were in response to German influence appearing in the form of Danish Hegelianism. He writes: "This essay is a counter narrative to Kierkegaard the German philosopher; it is a counter narrative to the notion of boundaries of thought. For a moment, let us posit Kierkegaard as a Golden Age reader, a reader of the native tongue, a current reader and the currently read, in the hopes of illuminating the Byrony of Kierkegaard." For Gurley, Kierkegaard's impulse to mask comes from his Byrony, a poetic relationship intrinsic to his sense of aesthetic masking. Gurley's essay suggests that the aesthetic comportment of an authorship opens up interpretative possibilities beyond the surface of its assertions. 
M.G. Piety depicts another Kierkegaardian concern that lies outside of a rebuttal to German idealism, and while her essay, "The Stillness of History: Søren Kierkegaard and German Mysticism," depicts a connection to this movement in an oblique sense, it goes beyond a mere description of an affinity. She contextualizes her approach thusly: "The German mystics were particularly important for Kierkegaard because of the proximity of Germany to Denmark and because of their influence on both German idealism and the Pietist tradition in which Kierkegaard was raised." Piety analyzes the Danish thinker's theory of knowledge in light of the work of Meister Ekhardt and Johannes Tauler, and she illustrates how "Kierkegaard's own religious epistemology [...] makes clear that it is largely indistinguishable from the epistemology of Ekhardt and Tauler."

David Kangas' contribution concerns itself with theological matters from another perspective. His essay, "Being Human: Kierkegaard's 1847 Discourses on the Lilies of the Field and the Birds of the Air," reads Kierkegaard's engagement with The Gospel of Matthew's dictum "Consider the lilies of the field and the birds of the air." Kangas explicates the passage through a reading of one of Kierkegaard's "two small books on this one passage." In this manner he convincingly illustrates how this particular Kierkegaardian engagement takes on the " gambit of idealist metaphysics," which justified "self-consciousness as the ground of the real." In his far-reaching analysis, he reveals his own critical engagement with German thought in his concluding remarks: "Kierkegaard's discourses must finally be understood in terms of a problematic inaugurated by Marguerite Porete and Meister Eckhart, according to which only that which lives "without a why" truly lives. This tradition reemerges with great force, even if in a transformed way, in the later thought of Heidegger." Kangas' contribution illustrates the way that Piety's fascinating depiction of Kierkegaardian engagements with German medieval theological concerns re-emerge as part of the philosophical horizon of the late Heidegger.

With Michelle Kosch's "The Ethical Context of Either/Or," we turn to Kierkegaard's engagement with questions arising out of German Idealism's own multiplicity. In this "sequel to an earlier paper ('Kierkegaard's Ethicist' Archiv 
2006)," Kosch rigorously takes us through the ethical models and commitments available to Kierkegaard in his intellectual environment. She argues that work of J.G. Fichte "was the primary historical model for the ethical standpoint described in Kierkegaard's Either/Or II." Kosch provides us with a closely read analysis of both texts and she explains that "[i]t would be too generous to say that Either/Or I/ contains an account of practical reasoning; at best it contains a gesture at such an account. Still, some commitments can be drawn fairly straightforwardly from the text, and others can be assumed as the only way of accounting for some conjunction of textual clues."

Leonardo Lisi also engages with the stemning from which Either/Or emerged, providing us with a nuanced and far-reaching reading of the pseudonym A's essay from the first volume, "The Tragic in Ancient Drama Reflected in the Tragic in Modern Drama." Lisi explains that this essay is "possibly among the most frequently discussed and misunderstood" of Kierkegaard's works. He attributes these misunderstandings to "the tendency in the scholarly literature to view the text in light of Hegel's more famous theory of tragedy." In his own essay, "Tragedy, History, and the Form of Philosophy in Either/Or," Lisi shows how previous readings have "obscured the originality of Kierkegaard's contribution, which centers on two basic claims of far-reaching consequences for the theory of the genre and for philosophy more generally."

The next two essays take on a comparative analysis of Kierkegaard and Friedrich Nietzsche. To our knowledge, Nietzsche most probably never read Kierkegaard, and at best read the Danish literary scholar Georg Brandes' book on his fellow countryman. However, there are both dramatic affinities and differences in the work of these two philosophers both intensely concerned with lived experience. Daniel Conway wrote the first of these essays and provides the reader with an analysis that highlights a distinct complementarity that emerges when one thinks with these two philosophers together. "The Happiness of 'Slight Superiority"': Kierkegaard and Nietzsche on Resentment performs a Nietzschean vivisection on Johannes de Silentio, Kierkegaard's pseudonym in Fear and Trembling. Conway is chiefly "concerned to juxtapose their complementary 
investigations into the etiology and operation of resentment, which both thinkers identified as exerting a powerfully retardant force within the bourgeois societies of late modern European culture." His analysis avails itself of a reading of the ironic distance that Kierkegaard takes from his pseudonym and while Conway's main target is de Silentio, he makes the larger claim that the pseudonyms in general often "unwittingly bespeak, or manifest, a structural element of the spiritual crisis they seek to document."

The next essay is my own. "Clouds: The Tyranny of Irony over Philosophy" argues that there are distinct commonalities in the work of Kierkegaard and Nietzsche, which inform us about their conception of epistemological limits and their critique of modernity. One of these shared concerns was Socrates: "[...] Socratic irony became interesting for both of these thinkers for they understood that the multiplicity of perspectives that emerged after his death informs us about the centrality of interpretation in the conception of a culture. In other words, the death of Socrates, a primal scene in the history of Western thought becomes a moment where perspectives emerge and compete for primacy, where the present becomes a moment that contests the past, for the sake of posterity... In other words, Kierkegaard and Nietzsche conducted their critique of modernity from the standpoint of modernity, by ironically engaging with the ancients, by reanimating the idea of history, consequently showing the fair hair of progress to have dark roots."

The next two essays speak to traces of Kierkegaard's work in twentieth century German thought, although like the other essays in this volume, it would be reductive to depict these contributions as meditations on reception or influence. The first of these essays, Jeffrey Librett's "How to Go Beyond an Ontotheology of the Human Subject?: Anxiety in Kierkegaard and Heidegger" interrogates Martin Heidegger's rather ambivalent engagement with Kierkegaard's conception of anxiety as it relates to the temporal dimension of a critique of subjectivity. Librett asks "How far does Kierkegaard take us-and in what ways does he block us from proceeding-along the road to understanding how human beings exist in time, and how time structures human existence?" but 
his concerns reach further: "This conversation remains of interest because we are living in an age-a post-Enlightenment, ambivalently secularized age-in which we are still caught between, on the one hand, a subjective truth or a subjectivity of truth made possible and necessary by the privatization of faith, i.e. by "tolerance," and on the other hand, a public discourse of rationality, scientific and/or philosophical, that would replace the objectivity of pre-Enlightenment discourses of revelation."

Martin Klebes' contribution, "Mutiny of an Error: Wittgenstein and Kierkegaard on Suicide" concludes the volume. Klebes informs us of a delicious irony; Wittgenstein admired Kierkegaard's depths but wondered whether his aesthetic strategy of indirect communication could adequately convey existential concerns. Klebes writes: "Wittgenstein's ambiguous attitude towards Kierkegaard as a writer, shifting as it does between humbled admiration for the 'depth' of the Danish philosopher on the one hand, and critical assessment of the very idea of such 'depth' from the point of view of what we might call the legible surface of human behavior on the other." In this way our volume comes full circle, from Gurley's celebration of the poetic mask to Klebes' depiction of Wittgenstein's critique of what he understood as the limits of aesthetics.

\section{Acknowledgements}

The essays in this volume are for the most part elaborations on papers presented at the 2012 Conference, Kierkegaard and German Thought held at the University of Oregon. I would like to acknowledge three contributors to that conference whose papers do not appear in this volume. Charles Scott, Rocío Zambrana, and Vanessa Rumble all enriched our experience in the spring of 2012 by delivering brilliant and compelling presentations. This rich volume would be even richer if their contributions were included. I would also like to thank Alexis Smith, whose tireless editorial work made this issue of Konturen possible. I would like to convey my gratitude to Jacob Barto, Eva Hoffman, Judith Lechner, Nicholas Reynolds, Robert Mottram, and Josiah Simon for their help copy-editing the essays. Nothing would see the light of day without our production crew in the 
form of Sarah Grew. Barbara Ver West has been as always, an essential part of anything that happens here in the department of German and Scandinavian. Many thanks to Jeffrey Librett, who allowed me to conceive of this conference and issue of Konturen, and who has been an enormous resource throughout the process. Lastly, I would like to thank the contributors for the their brilliant essays and remarkable patience.

1 This text can be found in Søren Kierkegaard. Søren Kierkegaard Gjentagelse, Frygt og Bæven, Philosophiske Smuler, Begrebet Angest, Forord, SKS, 4, eds. Cappelørn, Garff, Kondrup, and Mortensen. Copenhagen: Gads Forlag 1997. 469, The English translation is from Søren Kierkegaard, Prefaces, trans. and ed. Todd W. Nichol. Princeton, New Jersey: Princeton University Press, 1997. 5.

${ }^{2}$ It is perhaps a point for further investigation that Cordelia, Johannes' object of seduction, compares him to a "matchless instrument" in A's prefatory remarks to The Seducer's Diary. See Søren Kierkegaard. Either/Or, Vol. 1. Trans. Hong and Hong. Princeton: New Jersey: Princeton University Press, 1987. 310.

${ }^{3}$ I believe that Swedish would be the lone exception here with att rösta meaning to vote and röst meaning voice. Agreement however is still expressed as det stämmer and stämning still means a mood or an atmosphere in an environment.

${ }^{4}$ The Hongs translate this as Exordium in the Princeton edition. See Hannay's Penguin edition for the translation of Stemning as attunement, which I think is correct.

${ }^{5}$ Voicing amplifies and articulates thought though incompletely; it is a modality of a stemning, an inflection or a refraction if you prefer.

${ }^{6}$ See Friedrich Nietzsche. The Gay Science. Trans. Josefine Nauckhoff. Ed. Bernard Williams. Cambridge, United Kingdom: Cambridge University Press, 2001. 5. See also the German, found in Morgenröte, Idyllen aus Messina, Die fröhliche Wissenschaft, KSA 3. Ed. Colli and Montinari. Berlin: de Gruyter, 1988. The German reads: "[...] und oft genug habe ich mich gefragt, ob nicht, im großen gerechtnet, Philosophie bisher überhaupt nur eine Auslegung des Leibes, und eine Misverständniss des Leibes gewesen ist." The citation is found on 348 in this edition.

${ }^{7}$ See Niels Thulstrup's Kierkegaard's Relationship to Hegel. Princeton: Princeton University Press, 2014. This monograph was originally published in 1980. See also Jon Stewart's Kierkegaard's Relations to Hegel Reconsidered. Cambridge, U.K.: Cambridge University Press, 2003. There is quite a bit of scholarship on 
this issue but these two books represent the clearest examples of the rejectionist thesis and Stewart's more nuanced counter argument.

${ }^{8}$ Kierkegaard's great enthusiasm about Schelling diminished with equal intensity as the lectures wore on. He remarks about them extensively in his letters. The trajectory of his experience can be discerned by regarding just a few excerpts from his correspondence. He expresses his initial excitement to P.J. Spang on November 18, 1841, writing: "[...]l have put my trust in Schelling...It may well blossom [the flowering of science] during the first lectures, and if so one might gladly risk one's life." By February 6, 1842 this fire had dampened and he had begun to concentrate on the writing of Either/Or. However, like most events in Kierkegaard's life there is a tangible divide between his desire to control perceptions and his true feelings. Despite this his distaste for Schelling's lectures is clear. A letter to his good friend Emil Boesen, dated on the $6^{\text {th }}$, discusses his reasons for leaving Regine Olsen and his desire not to be perceived as returning to Copenhagen because of her. He writes: "Please say that the reason for my return is that I am extremely dissatisfied with Schelling, which by the way is only too true." Finally, in a letter to his brother P.C. (Peter Christian) Kierkegaard also dated in February of 1842, he begins: "Schelling talks the most insufferable nonsense." Later in the letter he writes: "I am too old to attend lectures, just as Schelling is too old to give them. His whole doctrine of potencies betrays the highest degree of impotence." These citations can be found in Kierkegaard: Letters and Documents. Trans. Henrik Rosenmeier. Princeton, New Jersey: Princeton University Press, 1978. 99, 137 and 141.

${ }^{9}$ See Theodor Adorno, Kierkegaard: Construction of the Aesthetic. Trans. Robert Hullet-Kentnor. Minneapolis: University of Minnesota Press, 1989. 